\title{
Occupational asthma due to oil mists
}

\author{
A S ROBERTSON, D C WEIR, P SHERWOOD BURGE \\ From the Occupational Lung Disease Unit, East Birmingham Hospital, Birmingham
}

\begin{abstract}
Twenty five patients who were exposed to oil mists at their place of work were $\stackrel{O}{\vec{x}}$ investigated for possible work related asthma. Serial peak expiratory flow recordings showed 13 to have definite work related asthma, seven equivocal work related asthma, and three asthma unrelated $\underset{\omega}{\omega}$ to work; two had normal recordings. Subjects with work related asthma often produced different iv patterns of peak flow response during the working week; patterns also varied between patients. Six of $\odot$

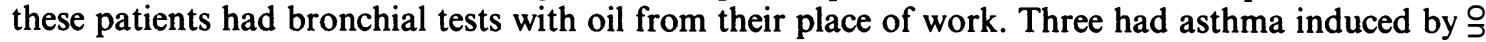
exposure to unused (clean) soluble oil and one reacted to used but not to clean oil. The challenge tests $\vec{r}$ in the remaining two gave inconclusive results. It is concluded that occupational asthma due to oil mists is common, the peak flow response is heterogeneous, and the provoking agent within the oil may $\frac{\widehat{\partial}}{\mathrm{a}}$ vary from worker to worker.
\end{abstract}

Many workers, particularly in machine shops, are occupationally exposed to oil mists. These may occur in high concentrations and often more than one oil is in use. 'Industrial oils are in common use as coolants, cutting fluids, and lubricants. Three major classes of oils are used: ${ }^{2}(a)$ mineral oil, which may simply contain an extreme pressure additive; $(b)$ emulsified mineral oil, which besides mineral oil and water contains emulsifiers, corrosion inhibitors, germicides, colourants, anti-foamers, extreme pressure additives, and perfumes (reoderants); $(c)$ synthetic oils, which are also mixed with water and which contain the same additives as the emulsified oils but with the mineral oil replaced by a "synthetic oil," such as a polyglycol. Oil diluted with water is often referred to as suds oils. The ultimate composition of the oil mist produced in the industrial setting depends on the type of oil used and the contamination that occurs with use, both from the metal that is being cut and from microbiological contamination, the latter being a particular problem with suds oil. ${ }^{34}$

Exposure to oil mists at work can give rise to several different health problems. ${ }^{5}$ Reports of respiratory problems related to the inhalation of oil were initially limited to the description of lipoid pneumonia, ${ }^{6-9}$ though the occurrence of this condition is probably rare. Some reports have suggested an association with pulmonary fibrosis, ${ }^{111}$ but the evidence for this is inconclusive. Oil mists have also been proposed as a

Address for reprint requests: $\operatorname{Dr} A$ S Robertson, Occupational Lung Disease Unit, East Birmingham Hospital, Birmingham B9 5ST.

Accepted 19 November 1987 possible cause of lung cancer, ${ }^{1213}$ but this is unlikely. ${ }^{1415}$ Despite the fact that respiratory symptoms are more common in workers exposed to oil mists ${ }^{1617}$ and are related to the ambient concentration of oil aerosol, ${ }^{17}$ only one survey so far has shown a reduction in spirometric values in exposed workers." This was apparent only when results were compared with predicted values, there being no significant difference between oil mist exposed and non-exposed workers. Other studies showed no deterioration in single spirometric measurements. ${ }^{141617}$ We have previously reported a case of occupational asthma induced by oil mists. ${ }^{18}$ We now report our findings in 25 workers exposed to oil mists with symptoms suggesting work related asthma. Six of these workers had a bronchial provocation test with the oil they used at work.

\section{Methods}

We studied 25 patients exposed to oil mists at work and referred to an occupational respiratory clinic with asthmatic symptoms that improved on days away from work. None was identified by epidemiological 2 survey. Details were obtained of the type of jobs $\stackrel{\varrho}{\subset}$ associated with exposure to oil mists and the nature of $\mathbb{D}$ the oils used. Length of exposure to oil mists and the time to the onset of the first symptoms were also recorded. Forced expiratory volume in one second $\frac{\vec{D}}{\mathrm{D}}$ $\left(F_{1}\right)$ and forced vital capacity (FVC) were $\stackrel{\odot}{\Phi}$

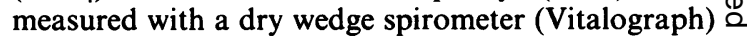
and expressed as a percentage of the predicted values. Skin prick tests were carried out with three common $\delta$ 
Table 1 Details of workers exposed to oil mist, grouped according to the relationship of asthma to work

\begin{tabular}{|c|c|c|c|c|c|c|c|c|c|c|c|c|}
\hline \multirow[b]{2}{*}{$\begin{array}{l}\text { Subject } \\
\text { No }\end{array}$} & \multirow[b]{2}{*}{ Sex } & \multirow[b]{2}{*}{ Age (y) } & \multirow[b]{2}{*}{$J o b$} & \multirow[b]{2}{*}{ Oil type } & \multirow{2}{*}{$\begin{array}{l}\text { Length of } \\
\text { exposure } \\
(y)\end{array}$} & \multirow{2}{*}{$\begin{array}{l}\text { Time to } \\
\text { first } \\
\text { symptoms } \\
(y)\end{array}$} & \multicolumn{2}{|l|}{ Initial } & \multirow[b]{2}{*}{$\begin{array}{l}\text { Peak flow } \\
\text { pattern }\end{array}$} & \multirow[b]{2}{*}{$\begin{array}{l}\lg E \\
(I U / \mathrm{ml})\end{array}$} & \multirow[b]{2}{*}{$\begin{array}{l}\text { Smoking } \\
\text { history }\end{array}$} & \multirow[b]{2}{*}{$\begin{array}{l}\text { Skin } \\
\text { test } \\
\text { result }\end{array}$} \\
\hline & & & & & & & $\begin{array}{l}F E V_{1} \\
\text { (\% prec }\end{array}$ & $\begin{array}{c}F V C \\
\text { dicted) }\end{array}$ & & & & \\
\hline \multicolumn{13}{|l|}{ DEFINITE } \\
\hline 1 & $\mathbf{M}$ & 67 & Setter & Suds & 43 & 33 & 60 & 105 & Progr & 315 & Non & + \\
\hline 2 & $\mathbf{M}$ & 37 & Turner & Suds/min & 18 & 17 & 112 & 121 & 1st day & 40 & Curr & - \\
\hline 3 & $\mathbf{F}$ & 44 & Operator & Suds/min & 4 & 0.25 & 73 & 81 & Progr & 210 & Ex & + \\
\hline 4 & $\mathbf{M}$ & 64 & Grinder & Suds & 45 & 41 & 29 & 45 & Equiv & 1500 & Curr & + \\
\hline 5 & $\mathbf{M}$ & 64 & Setter & Suds & 6 & 4 & 50 & 74 & Progr & 65 & Non & - \\
\hline 6 & $\mathbf{M}$ & 36 & Setter & Suds & 13 & 8 & 102 & 112 & Progr & 45 & Ex & NA \\
\hline 7 & $\mathbf{M}$ & 55 & Manager & Suds & 3 & 1.5 & 80 & 102 & Progr & 115 & Ex & - \\
\hline 8 & M & 64 & Grinder & Suds & 15 & 12 & 85 & 85 & lst day & NA & Curr & NA \\
\hline 9 & $\mathbf{M}$ & 49 & Cutter & Suds & 16 & 14 & 68 & 82 & Progr & 45 & Non & + \\
\hline 10 & $\mathbf{M}$ & 57 & Setter & Suds & 26 & 20 & 30 & 64 & Progr & 55 & Curr & - \\
\hline 11 & $\mathbf{M}$ & 43 & Setter & Mineral & 3 & 1 & 65 & 86 & Progr & 260 & Non & + \\
\hline 12 & M & 51 & Setter & Suds & 37 & 35 & 73 & 89 & Progr & $<25$ & Non & - \\
\hline 13 & M & 32 & Analyst & Various & 3 & 0 & 73 & 102 & lst day & 625 & Ex & NA \\
\hline \multicolumn{13}{|l|}{ EQUIVOCAL } \\
\hline 14 & $\mathbf{M}$ & 58 & Setter & Suds & 56 & 53 & 109 & 122 & Progr & 150 & Ex & - \\
\hline 15 & $\mathbf{M}$ & 52 & Assembler & Lub oil & 33 & 23 & 42 & 72 & Progr & 125 & Ex & + \\
\hline 16 & M & 60 & Setter & Suds & 26 & 0 & 20 & 41 & Progr & 5 & Ex & - \\
\hline 17 & M & 67 & Oiler & Various & 10 & 6 & 30 & 65 & Progr & 350 & Curr & - \\
\hline 18 & M & 60 & Turner & Suds/min & 35 & & 77 & 108 & Midweek & 55 & Curr & + \\
\hline 19 & $\mathbf{M}$ & 23 & Setter & $\begin{array}{c}\text { Suds + lub } \\
\text { mineral }\end{array}$ & 7 & 0.25 & 82 & 91 & Progr & NA & Curr & + \\
\hline 20 & $\mathbf{M}$ & 54 & Grinder & Suds & 28 & 25 & 99 & 100 & Equiv & $<25$ & Curr & NA \\
\hline
\end{tabular}

Oil type: min-mineral; lub-lubricating. Peak flow pattern; Progr-progressive; Equiv-equivalent. Smoking history: Non-non-smoker; Ex-ex-smoker; Curr-current smoker. Skin test result: + positive; - negative; NA-not available.

allergens, house dust mite, grass pollen, and cat dander, and total IgE was also determined.

All patients were asked to record their own peak expiratory flow measurements two hourly from waking to sleeping, using a Wright's mini peak expiratory flow meter. Three readings were made on each occasion and the best two had to be within $201 / \mathrm{min}$. Jobs carried out and treatment taken were also recorded daily. Records were plotted and initially assessed for the presence of asthma (diurnal variation in peak expiratory flow rate $\geqslant 20 \%$ ). ${ }^{19}$ If asthma was present its relationship to work was defined as being either definite (work related changes in over $75 \%$ of working weeks), equivocal (work related changes in 25-75\% working weeks), or absent (work related changes in less than $25 \%$ of working weeks). In those

Table 2 Results of bronchial provocation tests on six subjects

\begin{tabular}{|c|c|c|c|c|c|c|c|}
\hline \multirow[b]{3}{*}{ Subject No } & \multirow[b]{3}{*}{ Challenge material } & \multirow[b]{3}{*}{ Concentration (\%) } & \multirow[b]{3}{*}{ Exposure (min) } & \multicolumn{4}{|c|}{ Reaction in FEV } \\
\hline & & & & \multicolumn{2}{|l|}{ Immediate } & \multicolumn{2}{|l|}{ Late } \\
\hline & & & & Time (min) & $\%$ fall & Time (h) & $\%$ fall \\
\hline \multirow[t]{2}{*}{1} & $\begin{array}{l}\text { Superedge } 4 \text { suds (Burmah-Castrol) } \\
\text { Biocide }\end{array}$ & $\begin{array}{l}100 \\
100\end{array}$ & $\begin{array}{l}30 \text { (stirred) } \\
30 \text { (stirred) }\end{array}$ & 60 & $\begin{array}{l}23 \\
\text { No reaction }\end{array}$ & 6 & 10 \\
\hline & Reoderant & 100 & 30 (stirred) & 25 & & 7 & 14 \\
\hline \multirow[t]{3}{*}{2} & $\begin{array}{l}\text { Duracut (mineral) (Duckhams) } \\
\text { Unused B9 EP suds (RODS Oil Ltd) }\end{array}$ & $\begin{array}{r}100 \\
2\end{array}$ & $\begin{array}{l}30 \text { (stirred) } \\
5 \text { (neb) }\end{array}$ & & $\begin{array}{l}\text { No reaction } \\
\text { No reaction }\end{array}$ & & \\
\hline & Used B9 EP suds & 1 & 5 (neb) & 90 & 2 & 7 & 7 \\
\hline & Used B9 EP suds & 2 & 15 (neb) & 120 & 6 & 6 & 17 \\
\hline \multirow[t]{2}{*}{3} & Saline & 0.9 & 5 (neb) & 0 & 2 & 3 & 10 \\
\hline & $\begin{array}{l}\text { Unused Evco BRC3 Suds (Edgar } \\
\text { Vaughan) }\end{array}$ & $0 \cdot 1$ & 5 (neb) & 0 & 21 & 8 & 15 \\
\hline \multirow[t]{2}{*}{4} & Saline & 0.9 & 5 (neb) & & No reaction & & \\
\hline & Unused Hocut XL (Edgar Vaughan) & 1 & 5 (neb) & 10 & 11 & 2 & 19 \\
\hline \multirow[t]{3}{*}{5} & Saline & 0.9 & 5 (neb) & 15 & 4 & 8 & 10 \\
\hline & $\begin{array}{l}\text { Unused clearedge (Burmah-Castrol) } \\
\text { Unused clearedge }\end{array}$ & $\begin{array}{l}100 \\
100\end{array}$ & $\begin{array}{l}40 \text { (neb) } \\
30 \text { (hot stirred) }\end{array}$ & & $\begin{array}{l}\text { No reaction } \\
\text { No reaction }\end{array}$ & & \\
\hline & Unused clearedge & 1 & 5 (neb) & - & 0 & 11 & 9 \\
\hline \multirow[t]{2}{*}{6} & Unused clearedge & i & 5 (neb) & 15 & 1 & ii & 21 \\
\hline & Used clearedge & $\mathrm{i}$ & 5 (neb) & 50 & 13 & 11 & 15 \\
\hline
\end{tabular}

Neb-nebulised. 
with definite or equivocal work related asthma the pattern of fall in mean peak flow throughout the working week was classified into one of four previously defined groups: first day worse (fig 1), midweek worse (fig 1), progressive weekday deterioration (fig 2) or an equivalent weekday deterioration.

\section{BRONCHIAL PROVOCATION TESTS}

Six patients with definite work related asthma underwent bronchial provocation testing. The results in two cases are inconclusive.

\section{Case histories}

\section{SUBJECT 1}

This man was described in the first report of a case of asthma due to oil mists. ${ }^{18} \mathrm{He}$ was a toolsetter exposed to suds oil (table 1). Peak flow recordings showed a progressive deterioration throughout the working week with gradual improvement during a prolonged period away from work. Bronchial provocation tests were carried out with hard metals, emulsified oil (both used and clean) used at work, and several separate oil constituents. All oil challenges were carried out with stirred oil only. Appreciable reactions occurred in response to the emulsified oil (table 2). Subsequent

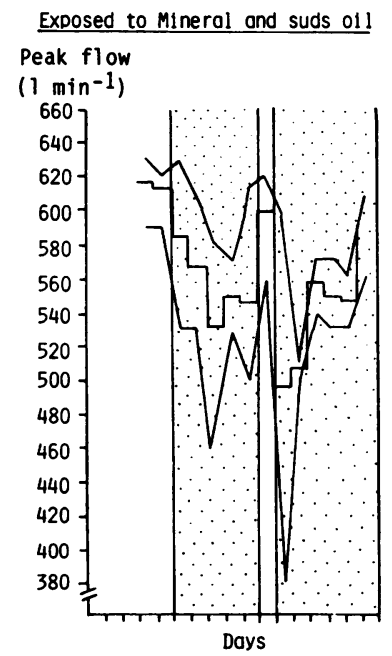

Mineral oll exposure only

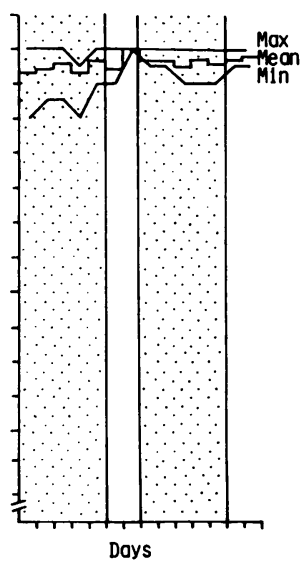

Fig 1 Daily mean, minimum, and maximum peak flow recordings from subject 2. Days at work are stippled. For the first two weeks he was exposed to both suds and mineral oil. During the first working week there was a midweek deterioration in mean peak flow followed by an improvement during the single day away from work. In the second working week mean peak flow shows a "first day worse" deterioration. In the second two week period, when he was exposed to mineral oil only, there was an improvement in his asthma, with no work related effect.

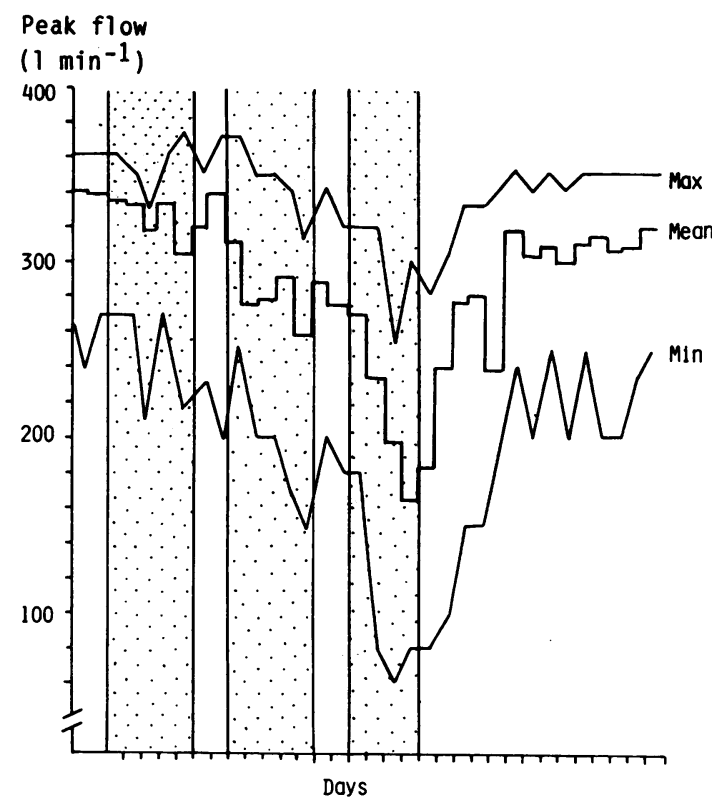

Fig 2 Peak flow recordings in subject 3 plotted as in figure 1, showing progressive deterioration in mean peak flow for the first three working weeks (stippled areas), followed by a consistent improvement during a more prolonged period away from work.

challenges with the constituents showed a positive reaction to the reoderant containing pine oil.

\section{SUBJECT 2}

A 37 year old machine tool operator had asthma that improved during holidays and was worse on work $\stackrel{0}{x}$ days, particularly on the first and second days back at $\frac{0}{3}$ work after a holiday. In his work he did metal turning, using concentrated mineral oil that produced little $O$ mist. He associated symptoms with the operation of a nearby bar grinder, which used a suds oil and $\frac{\text { 의 }}{2}$ produced a discernible mist and smell, particularly $D$ after a period of disuse. An assessment of his usual work exposure to oil mists was made by carrying out $N$ personal sampling with the patient in his usual place of work. The total oil concentration was $0.66 \mathrm{mg} / \mathrm{m}^{3}-\mathrm{O}$ three quarters of which was the soluble oil from the bar $\mathrm{\omega}$ grinder. Peak flow recordings confirmed work related asthma (fig 1). The asthma resolved during the work-e ing weeks when he was no longer exposed to suds oil $\mathbb{D}$ from the bar grinder but was still exposed to the $\stackrel{?}{+}$

mineral oil aerosol.
Bronchial provocation tests were performed with $\frac{0}{\overrightarrow{0}} \overrightarrow{\frac{1}{D}}$ the mineral oil from his turning machine, and with clean and used suds oil from the nearby bar grinder. $\stackrel{\mathbb{Q}}{\Omega}$ Culture of this oil produced a heavy growth of severalo organisms, including a Klebsiella species, a Bacillus 


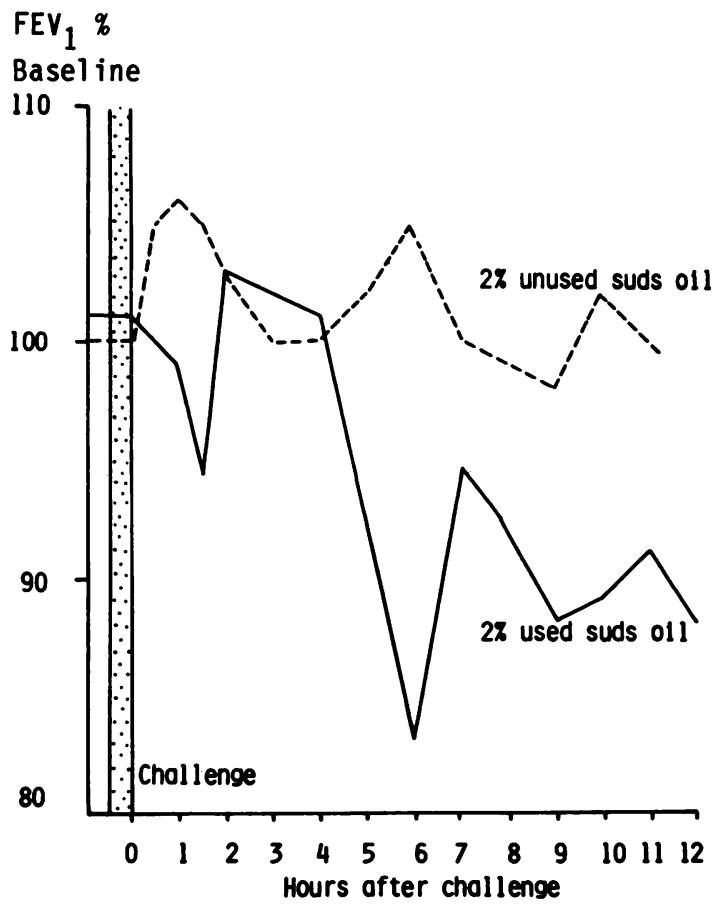

Fig 3 Percentage change from baseline for $F E V_{1}$ in subject 2 before and after inhalation challenges (shaded area). The dotted line shows FEV, after five minutes nebulised challenge to $2 \%$ unused suds oil. The continuous line is the FEV after a 15 minute nebulised challenge to $2 \%$ used suds oil.

species, and a Proteus species. The suds oil was diluted from its working concentration to concentrations of $1 \%$ and $2 \%$ by volume. A steady baseline FEV 1 was achieved before each provocation test. Initial tests were carried out with the undiluted mineral oil stirred for 30 minutes. He was subsequently challenged with the suds oil nebulised via an air driven Wright's nebuliser (see table 2). After an initial exposure for one minute spirometry was performed for 10 minutes, and if no significant fall in $\mathrm{FEV}_{\text {, }}$ had occurred the exposure was repeated for two minutes with spirometric measurements for a further 10 minutes. The exposure was repeated again if there was no significant fall in $\mathrm{FEV}_{1}$. An exposure of $3 \mathrm{mg} / \mathrm{m}^{3}$ of suds oil was achieved when a concentration of $1 \%$ was being used.

After provocation testing with the $2 \%$ used suds oil solution he developed a late asthmatic reaction, with the FEV, falling $17 \%$ six hours after challenge (fig 3 ).

\section{SUBJECT 3}

A 44 year old woman machine tool operator was exposed to both a suds oil and a mineral oil at work. Asthmatic symptoms were worse when she started work in the morning and again in the evening when she went home. Although symptoms improved tem-

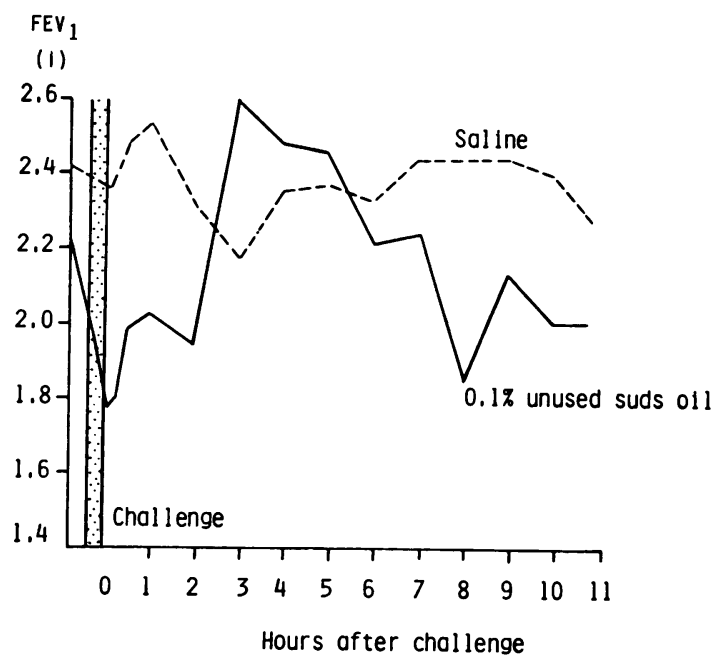

Fig $4 F E V$, before and after inhalation challenges in subject 3. The dotted line shows FEV, after five minutes' nebulised bronchial challenge to saline $0.9 \%$ and the continuous line the $F E V_{1}$, after clean oil at $0 \cdot 1 \%$ nebulised for five minutes.

porarily during weekends and holidays away from work they had gradually deteriorated over four years. Peak flow recordings showed considerable asthma, with progressive deterioration over the working week and recovery during periods away from work (fig 2).

Bronchial provocation tests were performed in a similar fashion to those of subject 2 (table 2) She developed a dual response to clean suds oil with an immediate fall in FEV 1 of $21 \%$ and a delayed fall at 8 hours of $15 \%$ (fig 4) with no change after a control challenge with saline. Further challenges with some of the constituents of the clean oil failed to show which agent was responsible.

\section{SUBJECT 4}

A 64 year old man had work that included both wet and dry grinding and cutting steel. The metals were cooled by a suds oil. Initially his breathlessness was better at weekends; as his symptoms progressed, however, this became less noticeable, although he still improved during longer periods away from work. Spirometry showed him to have substantial airways obstruction (FEV , 29\% predicted, FVC $45 \%$ predicted). The peak flow recordings showed small "equivalent" and "progressive" falls during the working week and a second day improvement after a day or days away from work. Provocation testing with clean suds oil at $1 \%$ produced an immediate fall in $\mathrm{FEV}_{1}$ of $11 \%$ at 10 minutes and a later fall of $19 \%$ at 2 hours (fig 5). There was no significant change after inhalational challenge with saline (table 2). 




Fig 5 Inhalation challenges (five minutes) in subject 4 performed with nebulised saline $0.9 \%$ (dotted line) and $1 \%$ clean suds oil (continuous line).

Of the 25 patients, 13 had definite work related asthma and seven had equivocal work related asthma (table 1). Three had asthma unrelated to work, and the records were normal in the remaining two. Most of the patients with work related asthma showed various patterns of peak flow response during the working weeks. A progressive deterioration throughout the working week was the most common pattern, being present in 14 out of 20 , and three patients in the "definite" group had a "first day worse" pattern.

Most of those affected were men, with a mean age of 52 (SD 12) years. All but one were engaged in or exposed to some form of machine tool operating (grinding, milling, turning). The one patient not exposed to machine tool operations, a gear box assembler, was exposed to a lubricating oil. The most common form of exposure was to suds oil alone (13/ 20 ), while 5 had mixed exposure to suds and mineral oils; only one was exposed to mineral oil alone. The mean length of exposure to oil mists was 21 (SD 16) years, with a mean latent period before the first symptoms of 16 (SD 16) years. The mean initial FEV and FVC as percentages of predicted were 68 (SD 27) and 87 (23) respectively. A total IgE $>70$ was found in nine out of 18 tested and eight out of 16 were skinprick positive.

\section{Discussion}

Previous studies have shown a considerable number of workers exposed to oil mists to have respiratory symptoms but failed to show a significant change in the mean lung function of exposed workers (both with and without symptoms). The sensitivity of single spirometric measurements in assessing occupational asthma is known to be poor.$^{19}$ In this study 20 out of 25 workers with work related respiratory symptoms were found to have probable or possible work related asthma. Within this group of patients we have found patterns of peak flow reaction to be heterogeneous $\frac{\widehat{\partial}}{\mathcal{C}}$ even within the same worker. A predominant pattern $\vec{\bullet}$ of progressive deterioration in peak flow waso associated with specific reactions to clean oils on bronchial provocation testing, both in subjects 3 and 4 을 described here and in the previously described subject $1 .^{18}$ First day worse deterioration in peak flow waso associated with a reaction only to used oil (subject 2).

Exposure to oil mists had mostly been of long음 duration and often there had been a considerable $\vec{\circ}$ latent period before the onset of symptoms. Suds oil 3 was the most common type of oil to give problems; but? whether more problems are associated with this type? of oil or whether it is simply the most common type of oil in use is unknown.

Reproduction by bronchial provocation tests of an oil mist exposure similar to that occurring at work is difficult. The mist of oil that occurs during work is generated when the coolant or lubricating oil falls on a응 hot spinning metal part. As we were reluctant to nebulise the oil directly we carried out initial chal-음 lenges with stirred oils, which were warmed only if no reaction occurred. This method of challenge releases only the volatile components contained within the oil. N This was successful in subject 1 , who was reacting to a pine reoderant; similar challenges given to further patients, however, showed that they were reacting tow another constituent, which required a set of differento challenge conditions. Discernible concentrations of oilo mist were found at work and these were reproduced by the use of a diluted nebulised challenge. Not all? challenges were successful and further work on 0 recreating a challenge similar to conditions at work웅 needs to be developed. We have not been able to $\stackrel{\square}{\Phi}$ produce inhalational challenge tests for both hot and $\stackrel{\mathbb{Q}}{\varrho}$ nebulised oils.

The present study shows that the problem of oil 
exposure at work is complex, partly because the constituents of any commercial product may be varied without change in the product name and partly because of the considerable contamination that occurs with use.

\section{References}

1 Hendricks NV, Collings GH, Dooley AE, Garett JT, Rather JB. A review of exposures to oil mist. Arch Environ Health 1962;4:139-45.

2 Jarvholm B. Cutting oil mist and bronchitis. Eur J Respir Dis 1982;63(suppl 118):79-83.

3 Hill EC. Two concepts of industrial disease. Occup Health 1967;Sep/Oct:245-6.

4 Bennett EO. The deterioration of metal cutting fluids. Progress in Industrial Microbiology 1974;13:121-49.

5 Waldron HA. Exposure to oil mist in industry. J Soc Occup Med 1977;27:45-9.

6 Laughlen GF. Pneumonia following naso-pharyngeal injections of oil. Am J Pathol 1925;1:407-14.

7 Proudfit JP, van Ordstrand HS, Miller CW. Chronic lipoid pneumonia following occupational exposure. Arch Ind Hyg Occup Med 1950;1:105-11.

8 Cullen MR, Balmes JR, Robins JM, Walker-Smith GJ. Lipid pneumonia caused by oil mist exposure from a steel rolling tandem mill. Am J Ind Med 1981;2:51-8.

9 Foe RB, Bigham RS. Lipid pneumonia following occupational exposure to oil spray. JAMA 1954; 155:33-4.

10 Jones JG. An investigation into the effects of exposure to an oil mist on workers in a mill for the cold reduction of steel strip. Ann Occup Hyg 1961;3:264-71.

11 Skyberg K, Ronneberg A, Kamoy J-I, Dale K, Borgersen A. Pulmonary fibrosis in cable plant workers exposed to mist and vapor of petroleum distillates. Environ Res 1986;40:261-73.

12 Huguenin R, Fauvet J, Mazabraud M. Rôle eventuel des nebulisations d'huile industrielles dans la pathogenie des cancers broncho-pulmonaire. Arch Mal Prof 1950; 11:48.

13 Holmes JG, Kipling MD, Waterhouse JAH. Subsequent malignancies in men with scrotal epithelioma. Lancet 1970;ii:214-5.

14 Ely TS, Pedley SF, Hearne FT, Stille WT. A study of mortality, symptoms and respiratory function in humans occupationally exposed to oil mist. J Occup Med 1970;12:253-61.

15 Goldstein DH, Benoit JN, Tyroler HA. An epidemiologic study of an oil mist exposure. Arch Environ Health 1970;21:600-3.

16 Jarvholm B, Bake B, Lavenius B, Thiringer G, Vokmann R. Respiratory symptoms and lung function in oil mistexposed workers. J Occup Med 1982;24:473-9.

17 Oxhoj H, Andreasen H, Henius UM. Respiratory symptoms and ventilatory lung function in machine shop workers exposed to coolant-lubricants. Eur J Respir Dis 1982;63(suppl 118):85-9.

18 Hendy MS, Beattie BE, Burge PS. Occupational asthma due to an emulsified oil mist. Br J Ind Med 1985;42: 51-4.

19 Burge PS. Single and serial measurements of lung function in the diagnosis of occupational asthma. Eur $J$ Respir Dis 1982;63(suppl 123):47-59. 